Исидора Д. Ђоловић*

\title{
ЕЛЕМЕНТИ ГРОТЕСКЕ У УМЕТНИЧКИМ БАЈКАМА АНДЕРСЕНА И ВАЈЛДА
}

\begin{abstract}
Од дидактичког до естетичког, од фолклорног изворишта до уметничких исходишта, бајка као књижевни жанр бележи необичан развојни пут, који се грана у различитим правцима. Никада сасвим лишена мрачног, опомињућег подтекста, почев од романтичарске епохе добија додатне слојеве и с једне стране појачану стилизацију, а с друге знатнији уплив гротескних и бизарних елемената. Све скупа води преиначавању из идиличне у злокобну, анти-бајковиту атмосферу. На одабраним примерима из Андерсенових и Вајлдових ауторских бајки, показаћемо резултате уношења обележја модерних поетичких струјања. Приметићемо трансформацију и усложњавање првобитног жанровског модела, те специфичан - а двоструки ефекат присуства гротеске, као естетског и прихолошког феномена.
\end{abstract}

Кључне речи: гротеска, уметничка бајка, романтизам, бизарно, деконструкција, онеобичавање, жанровска трансформација.

\section{1. Иновације које доноси уметничка бајка у смеру гротескног и злокобног}

Вековима су бајке средство забављања и подучавања младих нараштаја, а универзалношћу својих порука пратилац и стални ,учитељ“ зрелих, формираних људи. У зависности од сугестивности предоченог, мотиви и поуке следе нас кроз све етапе животног пута, као део „колективног кода“, својственог свакој средини и временској епохи. Остављен траг и његово преношење одржавају древност и потврђују како промишљено (и срећно) одабрана матрица- а ово важи за било који жанр- са успехом опстаје кроз разна варирања и манифестације, временом губећи националне и континенталне одлике, прерастајући у цивилизацијско културно добро.

isidoradj@yahoo.co.uk 
Бајка је најчешће дефинисана као прича са фантастичном садржином, натприродним бићима и магичним догађајима смештеним у неодређено време и простор. Првобитно намењене одраслој публици, временом су све више писане и усмераване ка деци. Трансформација усмене бајке у ауторску почиње у XVII веку, а упоредни развој наставио је да се одвија кроз међусобну размену топоса, ликова, заплета и осталих елемената који чине срж структуре фантастичних прича. Са кореном у народним предањима, почев од делатности Шарла Пероа и браће Грим прилагођавају се писаној форми. Прелази се пут од записивања и прераде до преобликовања у самосталну пишчеву творевину. Тако Андерсен из усмене бајке узима теме и мотиве, али, чини корак даље и ,уместио сакуйљача који иреиричава, gорађује и

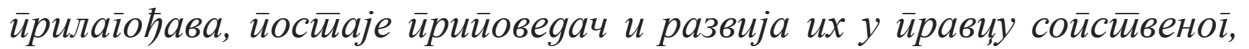
сйецифичноі сйила“"1. Пратимо развој жанра од тенденциозности до литерарности, од поучности до артизма, с тим што се првобитна намера никад не губи, већ подвргава наглашеној стилизацији. По речима Јована Љуштановића, изражава се слика које у традиционалној усменој бајци нема и асимилује у романтичарску слику света и схватање поезије. Ауторска бајка је „креација иесничке индивияуалносиии“, која грађу из фолклора подвргава преиначавању и обрнуто- „саgржаје из

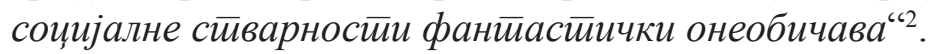

Свака књижевна епоха је користи,пружајући свој допринос. Интересовање за фолклор кулминира у романтизму, који у дела уводи индивидуално, зачудно, подсвесно, сан, култ уметника. Симболизам је уобличава, дајући дубљи смисао и изводећи је из оквира „немогуће приче за децу“ у почетни модел по коме се развијају многи каснији прозни жанрови. Естетизам и свест о узвишеној природи уметности коју обичан свет не разуме, биће мотив присутан већ у романтизму, а доминантан у симболизму. Може се рећи да од Андерсена бајка почиње да бива озбиљно схваћена- чита се и високо вреднује у свим слојевима публике (ово дугује и ширењу читалачког „тржишта“). Иако полазе од обрасца фолклорне бајке са свим њеним суровостима и бруталношћу (почев од опуса браће Грим), Андерсенова дела се чи-

1 Љубиша Рајић, „Андерсен на размеђима“, стр. 14.-15.

2 Јован Љуштановић, „Мале бајке Стевана Раичковића у контексту српске рецепције Ханса Кристијана Андерсена“, стр.78 
тају са уживањем због, до тада никад у тој мери, изразитог уметничког „печата““. Стилизацијом и иновацијама чини од бајке пуноправну, високо артистичку литерарну творевину. Оскар Вајлд ће кренути његовим трагом, довршити овај процес и у потпуности преиначити усмену бајку у мали манифест етике и естетике, стилско-језичку и тематску апологију врлине и лепоте. Са овим ствараоцима, ауторска бајка постаје збиља и - уметничка.

Али, да све не би деловало сувише једноставно и „зашећерено“, треба истаћи врло битну карактеристику и уједно новину коју дела ова два писца доносе. Необичност (,зачудно“ као изданак романтичарске поетике и омиљени украс њихове прозе и поезије) и „софистицирана страва“ кретаће се у наредним вековима развојном путањом до анти-бајке, анти-утопије, сатире, итд. Пародија и јако изражена ауто-поетичка свест (нарочито кроз коментаре) пратиће њихова дела и отворити простор за уплив гротеске. Уобичајено значење гротеске,

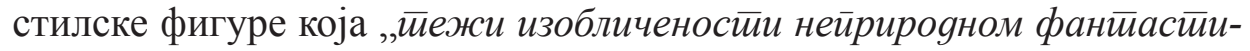

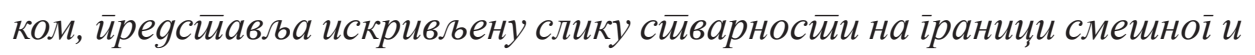

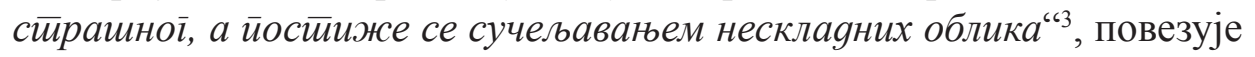
се са изазивањем истовремено непријатног осећања и сажаљења, емпатије. У суштини, реч је о спајању неспојивог и контрадикторности, које обично резултира ефектом изненађења. Најчешће особине су јој двострукост, хибридност и метаморфоза, а по неким схватањима можемо је уопштити као фундаментално егзистенцијално искуство, у вези са лабилношћу и променама идентитета. Отуда је врло привлачна свакој граничној, револуционарној стилској тенденцији. Ово ефектно уметничко средство буди код читалаца гнушање, али и болну нелагоду. Њена употреба сеже до митског слоја Овидијевих „Мейаморфоза“, као извора гротескних трансформација и хибридних створења.

Епоха романтизма, у којој и Андерсен ствара, нарочито радо користи гротеску, пре свега у складу са својим занимањем за несвакидашње, необично, морбидне и граничне ситуације. Осим тога, гротеска својом природом која нарушава класичне моделе реда, разума, хармоније, равнотеже и култа форме, одговара романтичарској поетици која настоји да разори класицистичке норме. Фиктивни лико-

3 Тања Поповић, „Речник књижевних термина“ 
ви се обично сматрају гротескним уколико својом амбиваленцијом изазивају подједнако гнушање и саживљавање, подстакнуто честом физичком деформисаношћу или моралним дефектима. Романтичарска гротеска, за разлику од средњовековне која раблезијанским хумором слави смех као средство разоткривања, преусмерава се ка ужасу и злокобном. Низ књижевних јунака има управо такве одлике, а линију можемо пратити до Луиса Керола и његове галерије необичних појава из „Алисе у Земьи чуда“.

Ако је предодређено да лепота спаси свет, онда њена негација и изопачавање треба да одиграју улогу препреке, наруше идилично устројство и испровоцирају пружање отпора. Гротеска, приказ света посматраног кроз искривљену оптику, хотимично преокретање склада, разарање уједначеног и симетричног микрокосмоса приче, њихово је водеће средство. Гротеска служи фантастици управо испуњавајући њену потребу за деловањем преко ефеката - и то брзих, јаких, шокантних и упечатљивих. Гротеска и злокобно нису тек ,изум“романтичарске бајке, јер усмена предања - а крећући се дубоко у прошлост видећемо да је код митова још радикалнији случај (као, уосталом и већине пионирских плодова паганске имагинације)- обилују бруталним, дивљим, насилним призорима. Буђење страха и нелагоде у слушаоцу било је одувек средство које проверено делује. Из првобитне фолклорне суровости, која је код браће Грим још увек очигледна, прошавши кроз „филтер“ префињеног романтичарског и симболичарског израза, посредована је у споју са ренесансном карневалском, незграпном и изобличеношћу знаковитом сликовности. Елементи нестварног у додиру са свакодневним, претварање типског у појединачно, устаљеном пружа особеност, а поступцима поред спољње мотивације - удео психолошке и карактерне осветљености јунака. Трагични несклад света ${ }^{4}$ у који су смештени одговара гротескној поетици несклада.

Гротеска не мора нужно и експлицитно бити чисто естетска категорија, особина слике изразито нескладних облика. Можемо говорити и о гротескном: утиску, ефекту, расположењу које изазива било која несразмерност и неусклађеност односа или понашања у одређеној ситуацији. Гротеска је побуна против симетрије и не мора увек

4 Зорана Опачић-,Наслеђе Ханса Кристијана Андерсена у делу Гроздане Олујић“, стр.102 
ЕЛЕМЕНТИ ГРОТЕСКЕ У УМЕТНИЧКИМ БАЈКАМА АНДЕРСЕНА И ВАЈЛДА

деловати очигледно, нити се односити искључиво на спољње, физичке одлике. Гротескни су и поредак, устројство, окружење, било шта што се опире природном, уравнотеженом, било који вид преступања норми. Можемо је разликовати на основу две категорије:

1. Естетска- визуелна, спољашња, чулна (јер најпре делује преко изгледа ствари, експлицитна је и одмах уочљива);

2. Психолошка- унутрашња, скривена у осећају, утиску, атмосфери (усудићу се да је назовем интуитивном; не видимо је, али, осећамо њено присуство и посредована је другим средствима).

\section{2. Гротеска код Ханса Кристијана Андерсена}

Због свега наведеног, Андерсенове бајке се урезују дубоко у памћење читалаца. Њихова сликовитост је неретко бизарна, болна, застрашујућа, а мотиви превазилазе површно, махом једнозначно схватање књижевности за децу и позивају на удубљивање, будући да и сами потичу из дубина људског искуства и колективног памћења. Дански писац је можда најзаслужнији за афирмацију жанра уметничке бајке и то превасходно због иновација као што су: деконструкција и поигравање различитим дискурсима, додатна карактеризација јунака и залажење у психологизацију, коришћење ефекта изненађења (јако битне одлике гротеске), антропоморфизовање и очовечење природе и предмета, проблематизовање несклада и несналажења јунака у свету (које преокреће завршетак из срећног у трагичан). Гротеска представља значајни поступак у грађењу новог типа бајке, присутна је у мањој или већој мери, истиче њихов како стилски, тако и идејни слој.

Бајка „Оїьило“ користи сиже и мотиве из „1001 ноћи“, попут чаробног огњила које испуњава жеље, лепотице-принцезе коју јунаку доносе ноћи, обележавања свих кућа кредом како би се заварао траг, и сличних. Гротеска се први пут појављује на визуелном плану, појавом наказне вештице коју војник сусреће на свом путу (,gоља јој се усна

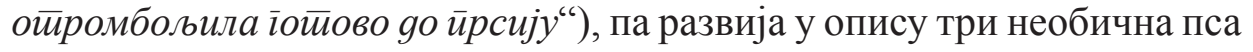
који испуњавају жеље (а имају очи „величине шоље оg чаја; млинскоі камена; окруїлих кула“), да би кулминирала у опису покоља на крају, када су судије, краљица и краљ раскомадани од стране паса, а војник постаје владар и добија принцезу за жену. Све је пропраћено иронич- 
ним коментарима приповедача, чиме се открива његова непосредна ангажованост.

У чувеној причи „Царево ново оgело“, поступак прелази у карневализацију, доводећи апсурд до врхунца кроз призоре варалица крај празног разбоја, док у ваздуху праве покрете симулирајући чин ткања, над непостојећим рухом. Случај се заоштрава у кључној сцени, где цар ступа необучен, док светина хвали „скуте“, које за њим „носи“ пратња. „Цвеће мале Иgе“ доноси поступак антропоморфизације биљака и предмета- па тако цвеће оживљава; девојчица у ониричком доживљају види њихов бал, на коме се појављује и изразито гротескна фигура воштаног лутка „на йоклаgном шйайу“, који ,луйка међу цввећем са своје йри рашљасйе ноїе“; поменимо и завршну слику сахране цвећа. Још један пример оживљавања артифицијелног налази се у бајци „Славуј“, у мотиву вештачке, аутоматизоване птице (још од Хофмановог „Пескара“ па до роботских фигура савремене научно-фантастичне прозе, давање покрета механичком изазива језу) која замењује правог, живог славуја и засењује дворјане својом сталном расположивошћу за коришћење. Осим очигледне, ту је и психолошка гротеска у понашању људи (даме које „,иуне устиа воgом, не би ли забиіллсале као и славуј“; пиљар који деци даје име по њему „маgа не знају gа йевају“") и односу дванаест царевих слугу, који славуја „воgе у шейьу са йо једном йанйљиком везаном за ноїу, како би їа боље сачували".

„Палчица“ најпре уводи буквализацију жеље у мотив чудесног рођења- жена пожели да има "мало gешес" и заиста добије сићушну девојчицу, из лалиног цвета. Њена лепота је стављена у гротескни однос „Преувеличано:мало“, „заносно:одвратно“, кроз спојеве „Палчица- крастава жаба“ и „Палчица- гундељ“, током њеног путовања и сусрета које јој оно доноси. Осим антропоморфизације, ефекат је појачан перспективом „из лупе“, а врхунац гротеске проналазимо у лику старог крт(ц)а ,y каgифеном крзну“, који у дубљем смислу репрезентује подземни свет и неку врсту даље асоцијације на мит о Персефони. Онеобичавање стварности доприноси читалачком утиску, а идилични поредак се поново успоставља тек доласком јунакиње у себи адекватно и сродно окружење. Појавом малени јунак има важну улогу и у бајци „Ружин вилењак“, која представља варијанту приче из ,Декамерона“, о девојци чијег вољеног младића потпуно немотивисано 
ЕЛЕМЕНТИ ГРОТЕСКЕ У УМЕТНИЧКИМ БАЈКАМА АНДЕРСЕНА И ВАЈЛДА

убије њен брат. Кроз сан јој тајну открива вилењак из ружиног цвета који је поклонила драгом на последњем састанку. Бизарни моменти почињу откривањем леша и сакривањем младићеве главе у саксији, чију земљу залива својим сузама, а настављају се серијом смртних случајева, до коначног извршења освете од стране пчела и духова из јасминовог цвета. Наравно, све ове бајке садрже гротеску у елементима, али, три су нарочито обележене овим стилским средством које им заправо пружа јединственост.

Вероватно најчувенија Андерсенова бајка, „Мала сирена“, у оригиналном тексту има мало шта од разиграности и безазлености Дизнијеве цртане верзије. Осим што је подтекстом приче проблематизовано хришћанско питање бесмртности душе и начина на који се оно заслужује, али и пут иницијације и сазревања, елементи гротеске су одиграли веома битну улогу. Присутни су већ у природи саме јунакиње и њених сродника- реч је о бићу које не припада људској врсти, већ је једном половином девојка, а другом риба. Живећи у подводном царству, она често одлази на површину и заноси се непознатим, а примамљивим чарима света на копну. Иако стално прелази границу између та два простора, она суштински није део ни једног, ни другог и тај дуалитет ће бити присутан до краја. Како би ипак приступила жељеном свету људи, она подноси велику жртву у царству застрашујуће морске вештице, које је већ преплављено претходним несрећним знатижељницима. Цена коју мора да плати, како би добила могућност стицања бесмртне душе кроз приближавање и покушај задобијања наклоности краљевића, јесте брутално одсецање језика и лишавање гласа, тј. способности звучне артикулације. Инсистира се на неуобичајености захтева тешког остварења жеље, а чин указује на неповратност, самим тим и тежину избора. Њен боравак на копну пун је сцена трагичних неспоразума и несналажења, да би непристајање на понуђени злочин довело до страдања, али и другачије могућности освајања свог места у вечности, кроз чињење добрих дела у новом облику постојања- као ваздушна вила.

Бајци „Снежна краљища““ придавана су бројна и различита значења, као и покушаји интерпретације. Уводна епизода са стварањем и распарчавањем ђавољег огледала обједињује хумор, сатиру и иронију, поступке пратеће гротескном свету који Кај посматра оком у које је 
заривен кобни комадић стакла. Измењена перцепција условиће путовање у ледени свет Краљичиног двора, где је окружују живописни поданици. За то време, девојчица Герта ће такође предузети путовање са намером да га врати, на коме (попут касније Алисе) наилази на низ интересантних јунака- од очовечених птица, преко дивље девојчице-харамбаше, до духова и очигледног уплива хришћанског контекста на трагу манихејског учења. Разарање гротескног леденог света и у овом случају доводи до спаса и поновног успостављања склада.

„Дивљи лабуgови“ су у целини обележени доминантним гротескним детаљима. Познати мотив зле маћехе, која прекида идилично одрастање Елизе и њених једанаесторо браће, употпуњен је мотивом претварања младића у дивље лабудове и крајње маштовитим језивим мучењима кроз која Елиза пролази од почетка до краја приче. Наиме, због љубоморе на пасторкину лепоту, маћеха ће најпре покушати да је нагрди у чувеној сцени стављања три жабе на њену косу,чело и срце док се купа, али, које се претварају у водене цветове услед девојчине чистоте и поштења. Затим ће је сама наружити мазањем блатом и учинити до те мере непрепознатљивом за оца да ће бити отерана од куће. Лутајући по шуми, вративши се правом обличју, она трага за браћом и открива да се једино ноћу преображавају у људска бића. Одлучују да је пренесу са собом у лету преко мора, али, хвата их ноћ, коју проводе драматично збијени на уској стени усред таласа. На новом тлу, Елиза у сну сазнаје начин скидања клетве и одлучује да се жртвује за браћу тако што ће исплести једанаест кошуља од коприве, у тишини. Уколико проговори, њиховим животима је крај. Цена је слична као у „Малој сирени“, с тим што ће овде главна јунакиња на крају срећно избећи смрт. Иако ће краљевић- који заносну нему девојку одводи себи у двор и узима за супругу, бити подозрив према њеној загонетној занимацији (чак јој адаптира одају налик на пећину, у којој су свуда распрострте коприве), чак и озбиљно подлећи оптужбама за вештичарење (након личног посведочења њеног ноћног одласка на гробље по коприву, која расте у непосредној близини састајалишта вештица које скрнаве гробове), на самој ломачи ће бити спашена појавом браће и њиховим преображајем који јој враћа могућност говора и самооправдања. Упадљив гротескни мотив на крају је крило које остаје уместо руке најмлађем брату, пошто услед журбе није стигла да доврши један, последњи рукав. Победом правде, свет гротеске се преображава 
ЕЛЕМЕНТИ ГРОТЕСКЕ У УМЕТНИЧКИМ БАЈКАМА АНДЕРСЕНА И ВАЈЛДА

у свет лепоте и чистоте- ломача постаје ружин грм, а бели цвет са њеног врха (,као звезда“) настањује се на Елизиним грудима, уместо оне наказне жабе са почетка. Почетна хармонија је враћена, па ипак, ово је једна од мотивски најбизарнијих бајки свих времена.

\section{3. Гротеска код Оскара Вајлда}

На примеру Вајлдовог дела прилично јасно можемо пратити настављање линије коју започиње епоха романтизма, са још наглашенијим заокретом ка модерни. Све иновативне особине се заоштравају, поготово аутопоетичка свест и тенденциозно коришћење посебног типа гротеске. У књижевност за децу овај знаменити и контроверзни писац закорачио је збирком „The Happy Prince and Other Tales“, која је објављена 1888. године и садржи пет прича. Оно што Вајлд, као директни и најочигледнији наследник Андерсена, такође уноси у своје бајке и што се најпре може препознати као утицај, јесу:

1. Естетичност нарочите врсте- тема односа уметности и света;

2. Хришћански подтекст и морализам- жртвовање за срећу ближњег, победа јунака над самим собом;

3. Отворен или двосмислен завршетак, тема смрти позитивног јунака, сукоб илузија и стварности;

4. Вишесмисленост и дубље значење приче, ширење и усложњавање модела бајке;

5. Иронијски коментари упућени друштву, сатирични призвук, јаки ефекти са циљем трајности поруке.

Општа тенденција свих његових бајки је да покажу како се етичка чистота и исправност могу постићи једино кроз одрицање, жртву и превазилажење, поништење себичне, охоле, похлепне природе. Упркос том јасном настојању, он најчешће проблематизује одлуку јунака, односно, крај није увек срећан ни праведан, што упућује на изопаченост друштва које обесмишљава племенита начела.

Бајка „Срећни ирини“ здружује артифицијелни кип, али са живим осећањима, уз живо биће, ласту- али, без свести о значају срца и његовог окретања другима. Одвајајући делове себе- рубине и сафиpe, као украсе мача и своје очи, статуа Принца ће их слати људима у 
невољи (сиромашној шваљи, младом драмском писцу, девојчици са шибицама- директно преузет Андерсенов мотив) и на тај начин учити ласту да, упознајући животну реалност, воли и саосећа. Изгубивши лепоту, допадљивост и сјај овим одрицањем, кип- након ластине смрти (мотив пуцања срца у статуи такође је у домену чудног)- бива одбачен и завршава у ливници, а његово срце на сметлишту. Као супротност њиховом односу, стоји површни свет грађанства са својим разговорима кроз које се пробија Вајлдова бритка критичка мисао.

„Себични gив“ за главног јунака има фантастично биће, у контрасту према деци, којој брани да се играју у његовој башти. Башта је својеврсна метонимија његовог срца, због чега у њој такође влада вечита зима. Када га љубав једног дечачића, испоставиће се- Христа, освести, посветиће живот и свој простор деци, тиме заслуживши селидбу у рајску башту након своје смрти. Поново је присутан мотив преображаја гротескног света (царство вечите студени, у коме борави џин) у идилични (пролеће, природа, деца блиска Богу), аналогно духовном преображају кроз који јунак пролази.

„Славуј и ружа“ је прича са средишњим мотивом жртве ради помоћи несрећно заљубљеном студенту. Како би му прибавио савршено црвену ружу, која је услов да девојку у коју је заљубљен изведе на плес, славуј ће певати груди прислоњених на трн, док крв из његовог умирућег тела даје ружи боју живих осећања и страсти. Опису његове трагичне и пресудне ноћне песме грубо је супротстављена слика добијене руже у уличном блату, где завршава након што је разочарани студент бацио- површна девојка га одбија из материјалних разлога, а он процењује љубав као бескорисну, вративши се књигама и метафизици. Схватање људи о славују као бесловесном бићу које не осећа и чија је песма лепа, али, празна- а с друге стране њихова сопствена безочност и противречност речи и дела, поцртавају поруку отуђености, преваге материјализма и позитивизма над емоцијама и уметничким заносом.

„Славна ракейа“ садржи елементе гротеске у онеобичавању слике света, очуђењу постигнутом кроз антропоморфизовање предмета и животиња. Прича се на тај начин развија у алегорију друштвених односа, особина појединаца, а све у сврхе исмевања. „Звезgан“ је бајка у којој препознајемо мотиве каснијих дела истог жанра српске ауторке Гроздане Олујић, а говори о путу детета са необичним знамењима и због тога неподношљиво охолог, ка откривању сопственог 
ЕЛЕМЕНТИ ГРОТЕСКЕ У УМЕТНИЧКИМ БАЈКАМА АНДЕРСЕНА И ВАЈЛДА

идентитета. Тај пут је уједно пун испаштања и искупљења, а на њему ће јунак научити да цени, помаже и буде скроман. Осим антропоморфизације животиња-помагача, присутан је и поступак маскирања и препознавања (отац краљ- губавац, мајка краљица- просјакиња), али и типичан вајлдовски моменат подривања завршетка приче. Када је већ све изокренуто, ни крај није срећан, па добијамо инверзију бајке. У „Инфанииином рођеняану“ гротескни детаљи су балсамовани леш супруге, који краљ удовац годинама чува, као и наказни патуљак усред природе и касније раскоши двора, који умире након суочавања са сопственим одразом у огледалу.

Напослетку, једна од каснијих Вајлдових прича је композицоно веома развијена „Рибар и юеіова сенка“, која садржи многе препознатљиве мотиве на трагу „Мале сирене“, „Пеиера Шлемила“ и „,Унguне“. Креће се од елемената источњачких легенди, са очаравајућим дескриптивнм деоницама, па све до фолклорних представа о вештицама и човековој души као сенки која се може одвојити и осамосталити, али и представљати његову тамну страну. Захтев је обрнут у односу на Андерсенову бајку- људска душа је препрека за остварење љубави јунака и сирене. Чудесно двојништво, гротескни свет натприродних бића, несклад јунака и околине, унутрашња колебљивост између жељеног и могућег- све ово води ка трагичном завршетку, обојеном познатом пишчевом иронијом и скептицизмом.

\section{4. Смисао гротеске у бајци: дидактички и анти-бајковни правац}

Гротеска је обично пратећи елемент ироније и сатире, а заједно са црним хумором појачава и истиче критику друштва или појединачних појава. Са друге стране, пратећи фантастично и злокобно, такође служи постизању јаких ефеката и делотворној упечатљивости слике. У првом случају, креће се у правцу дидактичности и морализаторске функције - гнушање и презриви смех требало би да у публици пробуде одбојност и отпор према социјално и етички неприхватљивом. У другом случају, делује се са намером буђења страха, нелагоде, па и туге, а правац који заузима јесте анти-бајковни, песимистичан и у складу са модерним намерама да се упозори на трагику која произилази из отуђености и дезинтеграције савремене индивидуе. Гротеск- 
но је окружење или појединци у њему, у зависности од тога ка којем пољу се усмерава пишчева тенденција.

Гротескни ефекат се постиже и спајањем узвишеног и баналног, стављањем једног у други/супротни контекст или амбијент. На тај начин предочава се неисправност датог призора. Смех који гротеска изазива је смех у грчу, гримаса која иза „раздраганости“ крије ледену језу. Представљени несклад буди потребу за исправљањем и враћањем у равнотежу. Ефекат носи, с једне стране, васпитно- поучни закључак, a с друге делује као освешћење и откривши наличје постојећег може развијати визију у смеру све драстичнијег и апсурднијег - како би тим заоштравањем утицао на свест читалаца. И згражавање и емпатија једнако захтевају поправку - носе јасну поруку да приказано не треба тако да изгледа. Гротеска је, дакле, попут одраза у искривљеном огледалу. Овај заокрет једнако одговара новом добу и уласку у модерну, колико је почетно одвајање од класицизма одговарало романтичарској поетици. И једна и друга епоха суочавају се са радикалном изменом визије света и појединца у њему, а индивидуа добија наглашено већи значај. Закорачивши у модерну, уметност и свет који описује долазе у положај бесмисла, дилема и потребе за дубоким и пажљивим промишљањем. У новом, мање него икада безазленом и невином свету, места за бајку у свом изворном облику више нема. Али, како је потреба за њоме вечита и неизоставна, уз извесне модификације и, изразимо се тако, нове инкарнације, остаје присутна. Линију започету од стране Андерсена, а настављену са Вајлдом, преузеће многи следбеници: од Керола и Баума, преко Орвела и Кафке, до Толкина- а бајка ће наставити да живи кроз жанровске варијације, али, са чврстим ослонцем у свом изворишту.

\section{Литература:}

Андерсен, Ханс Кристијан; „Бајке“, Дерета, Београд, 2001.

Вајлд, Оскар;„Срећни краљевић и gруіе бајке“, издавачко предузеће „Веселин Маслеша“, Сарајево, 1965.

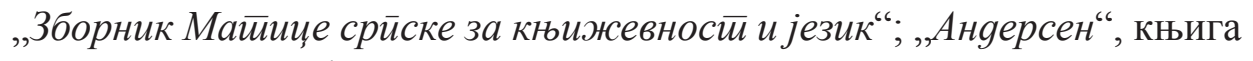
LV, свеска 1/2007.

Поповић, Тања; „Речник књижевних иеермина“, Logos Art, Београд, 2007. Тодоров, Цветан; „Увоg у фанйасиичну книюсевносӣ“, Рад, Београд, 1987. 
ЕЛЕМЕНТИ ГРОТЕСКЕ У УМЕТНИЧКИМ БАЈКАМА АНДЕРСЕНА И ВАЈЛДА

Isidora Đolović

\section{Summary}

\section{THE ELEMENTS OF THE GROTESQUE IN ANDERSEN AND WILDE'S ARTISTIC FAIRY TALES}

As a literary genre with both didactic ands aestehetic function, fairy tale developed from folklore origin to artistic form. Never completely devoided the dark, admonitory subtext, starting from romanticism it becomes fullfilled with additional layers and increased stylization on the one hand, and significant influence of grotesque and bizarre elements on the other. All together, these processes lead to redirecting from an idyllic to sinister, anti-fairy tale atmosphere, thanks to the presence of grotesque elements. From selected examples in fairy tales written by Hans Christian Andersen and Oscar Wilde, we tried to show the results of inputting the feautures of modern poetic directions. We'll particularly pay attention on the transformation of the genre and complexity of usual model, as well as a specific, double effect caused by the presence of the grotesque, as an aesthetic and psychological phenomenon.

Key words: grotesque, artistic fairy tale, Romanticism, bizzare, deconstruction, estrangement, genre transformation. 